\title{
Problem-Solving as a Governing Knowledge: "Skills"-Testing in PISA and PIAAC
}

\author{
Carol Bacchi \\ University of Adelaide, Adelaide, Australia \\ Email: carol.bacchi@adelaide.edu.au
}

How to cite this paper: Bacchi, C. (2020). Problem-Solving as a Governing Knowledge: "Skills"-Testing in PISA and PIAAC. Open Journal of Political Science, 10, 82-105.

https://doi.org/10.4236/ojps.2020.101007

Received: December 5, 2019

Accepted: December 28, 2019

Published: December 31, 2019

Copyright $\odot 2020$ by author(s) and Scientific Research Publishing Inc. This work is licensed under the Creative Commons Attribution International License (CC BY 4.0).

http://creativecommons.org/licenses/by/4.0/

(c) (i) Open Access

\begin{abstract}
This article scrutinizes critically a pervasive knowledge shaping contemporary sociopolitical relations and spaces-"problem-solving knowledge". It develops the argument that, as a governing knowledge, "problem-solving" is increasing in intensity and scope, with a range of negative and potentially dangerous effects. As a case study, the article examines how problem-solving knowledge operates in the OECD "skills" assessment programs PISA and PIAAC, with a particularly worrying connection between so-called "cognitive abilities" and labour market performance. It considers how this "turn to cognition", with its associated moralism, divides "citizens" into those who either can or who cannot solve "problems", producing "more productive" and "less productive" categories of people. More broadly, these programs illustrate how treating "problems" as self-evident referents is deeply depoliticizing, highlighting the importance of examining how governing takes place through problematization. Through tracing the emergence and functioning of "problem-solving" as a knowledge practice, the article encourages reflection on how problem-solving knowledge has come to be taken-for-granted as "truth" and on how it operates to limit political debate and to regulate political subjects.
\end{abstract}

\section{Keywords}

Problem-Solving, Poststructuralism, Problematizations, "Skills"-Testing, Cognitive Abilities, Genealogy

\section{Introduction}

This article scrutinizes critically a pervasive knowledge shaping contemporary political and social relations-"problem-solving knowledge". The concept of "problem-solving" is ubiquitous in everyday conversation and political debate. 
The words "problem-solving" may not always be used, but the underlying premise that "problems" or some other placeholder (e.g. "issues", "challenges", "concerns") need "solving" or "addressing" is pervasive. "Problem-solving" is treated as some sort of natural or innate capacity, describing How We Think, the title of John Dewey's 1910 book (Dewey, 1910) and "all of life", as in the title of Karl Popper's 1994 book, All Life is Problem Solving (Popper, 2013).

This article puts these propositions into question. It suggests the need to reflect on how we have come to think that thinking involves solving problems, and to consider the implications of accepting this view. To be clear, the goal is not to offer a new interpretation of how people think-the article is not a contribution to psychology-but to consider the political implications of a particular model of thinking, problem-solving ${ }^{1}$.

The article highlights two concerns: first, problem-solving knowledge divides "citizens" into those who either can or who cannot solve "problems", producing "more productive" and "less productive" categories of people; and second, problem-solving knowledge assumes the existence of discrete and self-evident "problems", detracting attention from the ways in which governing takes place through the creation of "problems" as particular sorts of problems-through problematization (see Bacchi 2009; Bacchi \& Goodwin, 2016). Hence, while "problem-solving" is commonly aligned with critical thinking, to the contrary, problem-solving, as a governing knowledge, creates politically quiescent, divided and self-regulating citizens.

The article proceeds in four parts. The next section introduces the Foucault-influenced poststructural stance informing the analysis. Section 3 offers an abbreviated genealogy of problem-solving knowledge, emphasizing the diversity in conceptions of problem-solving. Section 4 examines the place of problem-solving knowledge in the contemporary "skills"-testing programs PISA (Programme for International Student Assessment) and PIAAC (Programme for the International Assessment of Adult Competencies). Section 5 reviews strategies to disrupt problem-solving knowledge, and is followed by a short Conclusion.

\section{Background and Approach}

Calling problem-solving a "governing knowledge" indicates a poststructural approach to the topic. A knowledge, as used here, refers to the French sense of savoir as a form of background knowledge or "truth" discourse. This usage draws on Foucault's distinction between connaissance knowledge, to refer to specific disciplines, and savoir knowledge, to refer to the knowledge base necessary for ${ }^{1}$ Grammatically "problem-solving" should have a hyphen when it is an adjective but not when it is a noun. The author has adopted the convention of hyphenation in most cases to signal that, in its pervasiveness, problem-solving knowledge operates as an event, in the Foucauldian sense, "the interweaving of relations of power and domination" (Tamboukou, 1999: p. 207): "Events are not simply bits of data; they need to be analyzed in terms of the practices that give rise to them" (Bacchi \& Goodwin, 2016: p. 46). The hyphen in "problem-solving" is excluded when the term so appears in other publications. 
those disciplines to be produced (Bacchi \& Goodwin, 2016: pp. 35-36). As savoir, problem-solving knowledge is situated rather than transcendental. Borrowing John Law's (2009: p. 3) helpful phrase, it is a "contexted truth".

The term "governing", as in "a governing knowledge", refers to the practices of organizing and administering society, with no sense of conscious intent or manipulation. This term signals links to the analytic tradition of governmentality studies or an “analytics of government" (see Inda, 2005; Lemke, 2007). In this tradition attention is directed to the symbolic/material assemblages through which governing takes place, referred to as governmental technologies.

It is useful, therefore, to think about problem-solving knowledge as operating across three interconnected domains:

first, the domain of background knowledge (savoir);

second, the domain of disciplines (connaissances); and

third, the domain of governmental technologies, a topic pursued in Section 4 of the article.

Across these three domains problem-solving tends to be described either as a method of analysis (a procedure) or as a cognitive ability or skill, and often as both. As a procedure, problem-solving invokes the standard steps of scientific experimentation-problem recognition, hypothesis-testing and resolution. As a "cognitive ability", problem-solving is coming to be seen as a usable proxy for educational attainment, conventionally offered as a measure of a nation's "human capital".

The operation of human capital as a knowledge/discourse has attracted its due share of attention among critical scholars (Bacchi, 2009: pp. 217-219). The purpose of this article is to bring such critical scrutiny to problem-solving as a key governing logic of our age. To undertake this task, following Foucault, attention is directed to the interconnected sets of practices involved in the production of problem-solving knowledge, including practices of emergence, insertion/institutionalization and functioning (Foucault, 1972: p. 163; Foucault, 1991a: p. 65).

The next section traces the practices of emergence and institutionalization of problem-solving knowledge in an abbreviated genealogy. The subsequent Section 4 uses the OECD "skills"-testing programs, PISA and PIAAC, to illustrate the practices of functioning of problem-solving knowledge-the ways in which problem-solving knowledge operates to shape social and political relations in contemporary western societies and international organizations. Reflections on the possibility of disrupting problem-solving knowledge appear in Section 5, followed by a brief Conclusion.

\section{An Abbreviated Genealogy of Problem-Solving Knowledge (Practices of Emergence and Insertion/Institutionalization)}

The starting point for this analysis is recognition that there is more than one incarnation of problem-solving, making generalizations dangerous. For heuristic purposes, the article distinguishes between a student (or child)-“friendly" confi- 
guration and a more "technocratic" version of problem-solving, which depends on "expert" management and which currently dominates the intellectual and policy landscape.

The point of a genealogy is to discern how we have got "here" from "there", with "here" in this instance signaling the dominance of "technocratic" ("expert-led") problem-solving knowledge. The emphasis in a genealogy is not on some linear narrative or path dependence but on the plurality of factors and influences that happened along the way. That plurality of factors comprises a discursive practice, otherwise referred to as an assemblage or a dispositif (Bacchi \& Bonham, 2014). What we find, in such a genealogical study, is nuance and complexity rather than a direct line of development. At the same time, it is important to reflect on the politics and power that lead to the promotion of certain developments rather than others, all the while acknowledging the contestation surrounding those developments.

Turning first to the domain of background knowledge, as noted at the outset, we all talk about "solving problems". We hear and use the phrase every day in news reports on diverse topics. Government officials report on their efforts to solve problems on a regular basis. Policy-making is understood in terms of efforts to solve "problems-that-exist". Our classrooms are dedicated to extending problem-solving "skills". Even researchers who raise critical questions about problem-solving often lapse into talking about "problems", taken to be self-evident, that need to be "solved" (see Hajer \& Versteeg, 2005: p. 177).

Within the domain of disciplines, this powerful knowledge of problem-solving features prominently in the following fields: mathematics, medicine, public policy, social work, environmental studies, practice research, design thinking, business and management studies, public health, alcohol and other drug policy, law, psychology, criminology, international relations, and education, among others. Each area invites detailed analysis to discover how problem-solving knowledge has achieved such prominence and to indicate important debates and contestation about its status. Here, mathematics, science studies, policy development, and education studies (including learning theories) are offered as exemplars.

Turning a genealogical lens onto mathematics, where problem-solving clearly holds a privileged place, there is dispute about the very nature of problem-solving and the meaning of "problems". Writing in 1992, Alan Schoenfeld notes that, while "there is general acceptance of the idea that the primary goal of mathematical instruction should be to have students become competent problem solvers", "given the multiple interpretations of the term, the goal is hardly clear" (Schoenfeld, 1992: p. 334). In a 2017 OECD publication dedicated to elucidating The Nature of Problem Solving (Csapó \& Funke, 2017), John Dossey (2017: p. 60) concurs:

While problem solving is at the heart of mathematics, there is little agreement in the field about what problem solving is, what its boundaries are, or how it is best learned or taught to students in schools or practised in adult 
life.

Going further, Dossey quotes Gian-Carlo Rota, the "famed combinatorialist", who wrote:

Why don't we tell the truth? No one has the faintest idea how the process of scientific induction works and by calling it a "process" we may be already making a dangerous assumption (Rota, 1986: p. 263 in Dossey, 2017: p. 60).

For those looking to mathematics for a reliable model of problem-solving, therefore, it may be necessary to look elsewhere.

In the scientific field, however, basic parameters are equally nebulous. STS (Science and Technology Studies) scholars have been prominent in contextualizing the meaning of "problems" and "problem-solving" in science studies. Bruno Latour (1980: p. 53) refers to the "small word 'problem"” as a "folk term" in science that ought to be subjected to sociological analysis, alongside other such terms. He praises his colleague, Michel Callon, for initiating such a project. Callon's (1980) study of fuel cells and energy production reflected on how rival researchers actively produced the "problems" they studied-nowhere could "problems" be taken as the "origin of the research, nor purely cognitive" (Krohn, 1980: xiv).

In policy studies there is a long tradition that focuses precisely on problem-solving as a method of analysis. This tradition includes the classic rational policy-making framework associated with Marshall Dimock (1958), Herbert Alexander Simon (1961/1945), Eugene Bardach (1981), and Harold Lasswell. Lasswell's (1951) "problem orientation" made scientific problem-solving "the defining characteristic of policy analysis" and the "policy sciences" (Turnbull, 2008a: p. 73).

Howlett (2010: p. 9) offers a contemporary version of this tradition. He uses the policy cycle, with its stages of "problem recognition", "proposal of solution", "selection of solution", "putting solution into effect" and "monitoring results", as a guide to policy-making. In addition, evidence-based policy, which for several decades has dominated policy initiatives and discussion in many countries, relies upon a problem-solving logic. This logic is indicated in the well-worn mantra "what works". That is, interventions are tested to see "what works" to "fix" pre-set and taken-for-granted "problems" (Bacchi, 2009: pp. 252-255).

As part of this abbreviated genealogy it is important to recognize the many interventions in the policy field that are committed to challenging "technocratic" problem-solving. A wide range of interpretive studies, including those involved in exploring problem definition (Dery, 1984) and problem framing (Entman, 1993), problem setting (Turnbull, 2008b: p. 59) and problem posing (Fischer, 2003: p. 216), put in question technocratic approaches to "given" problems.

However, in the main, these studies continue to treat problems as self-evident referents (for exception see Kurze \& Lenschow, 2018). For example, Hajer and Versteeg (2005: p. 177; emphasis added) refer to the need to examine the views 
of the "people involved in finding solutions to environmental problems" in order to "get at a deep understanding of what the problem 'really' is". Such interpretive studies target for analysis the competing conceptualizations of "problems-that-exist" produced by different groups of actors. The objective is to create a space for negotiating "mutual integration of arguments", with consensus a desired outcome (see Bacchi, 2015a).

Bacchi's (2009) "What's the Problem Represented to be?" (WPR) approach offers a more substantive form of critique. Instead of focusing on how "problems" are "linguistically constructed" by various groups of actors (Hajer \& Versteeg, 2011: p. 688), it examines how governing takes place through problematizations-how "problems" are produced as particular sorts of problems within policies and with what effects. Therefore, instead of calling for "more tolerance for the multiple ways to tell the story of a policy problem" (Gottweis, 1998: pp. 334-335) it highlights the need to interrogate governmental problematizations (see Bacchi, 2015a).

In the WPR approach, there are no problems separate from their problematizations, meaning that governing takes place through problematizations, rather than through policies. As an analytic strategy, therefore, the WPR approach goes further than critiques that refer to the "elusiveness of the search to define the 'true' nature of a policy problem" (Gottweis, 2003: p. 263) or to problems as “wicked" (Head, 2008, 2018) or to "problematicity" (Turnbull \& Hoppe, 2018). It recasts the conventional "objects" of policy ("problems") and disrupts the assumed purposes of policy-making ("problem-solving”).

\subsection{Education and Models of Problem-Solving Knowledge}

Continuing our genealogical exploration, the field of education studies features prominently in the development of problem-solving knowledge, primarily through theories of learning. Returning to the heuristic distinction between "models" of problem-solving, a student-"friendly" version of problem-solving is associated with early twentieth-century functionalist psychology and American pragmatism, linked to the American philosopher John Dewey (Bredo, 1997: p. 6). There are connections also with more recent theories of situated learning (Lave, 2009) and cognitive constructivism (Temiz, 2013; Savery \& Duffy, 1996). The emphasis in these approaches is on students as active learners. In Dewey, students are directly involved in selecting the "problems" to be solved. Moreover, they are understood to move back and forth to "the problem", altering it or renegotiating it as learning takes place (Bredo, 1997: pp. 11-12).

The second model-the "technocratic", "expert-led" version of problem-solving-finds support within behaviouralism and cognitivism. As Bredo (1997: p. 30) describes, both these learning theories are committed to given, well-defined problems, "for without repetition of the 'same' problem, they would not know what 'learning' is". The prominent place accorded cognitive theory in contemporary OECD testing regimes, PISA and PIAAC, is a major theme in the 
next section of the article. The genealogical task becomes explaining the "victory" of cognitivist theory and the "failure" of student-friendly problem-solving.

Part of the explanation for this development can be found in ambiguity within Dewey's child-"friendly" problem-solving model, ambiguity that created an opening for technocratic developments. This ambiguity is due to Dewey's insistence on the existence of discernible, pre-existent starting points for "problems"- which he calls "indeterminate situations" - and his firm commitment to the scientific method (Shermis \& Barth, 1983: p. 88).

For Dewey, problem-solving is a response to an "indeterminate situation" associated with an existential "itch", a tension "which actuates a person to seek a solution". "Indeterminate situations" are conceptualized as "actual situations", as existing in fact. To resolve the tension produced by such "practical' troubles and difficulties" requires, says Dewey, a "new" way of thinking: a new way of processing information, based on the scientific method (Shermis \& Barth, 1983: p. 88).

Therefore, while children may be the ones who select the "problems" to "solve" in Deweyian problem-solving, these "problems" emerge from precognitive, existential "indeterminate situations", "actual situations which are themselves conflicting and confused" (Dewey, 1938: pp. 498-499). As Turnbull (2008b: p. 54) describes, social problems in Dewey similarly exist "independently of questions we might ask about them". To "solve" these "problems-that-exist", children and citizens are instructed to apply systematic and scientific problem-solving principles, which are taken-for-granted as "truth".

Richardson describes Dewey as "wavering between radically reformist stances in politics and his relatively optimistic and complacent embrace of technical expertise in the making of policy" (Richardson, 1998: p. 126; see also Fischer, 2000: p. 7). He (1998: p. 111) notes that Dewey's commitment to "empirical science" as a "tool" to "liberate action from the bonds of routine and caprice" can be seen to make Dewey a "friend of technocracy".

Dewey was not alone in his infatuation with science, a position common in "left" politics both in the United States and Europe in the early twentieth century (Howard, 2003: pp. 30-31). Empirical science was seen as "naturally opposing the rationalist and a priorist ideologies that legitimated traditional claims to authority by a church and a state that were viewed as serving only a narrow class interest" (Howard, 2003: pp. 30-31). In this post-Darwin world, science became the "savior" in the battle against dogma and the "ruling classes".

In Europe, the philosopher and sociologist, Otto Neurath, articulated this position in his 1929 Manifesto of the Vienna Circle.

one group of combatants, holding fast to traditional social forms, cultivates traditional attitudes of metaphysics and theology whose content has long since been superseded; while the other group, especially in central Europe, faces modern times, rejects these views and takes its stand on the ground of empirical science. (Neurath, Hahn, \& Carnap, 1929: p. 317 in Howard, 2003: p. 38; emphasis added) 
Howard (2003: p. 38) shows how Neurath defended this position using standpoint theory: "The objectivity of bourgeois science may be questionable, but that of proletarian science is not, because of the unique social and economic position of the proletariat as an oppressed class".

The companion movement in the United States, associated with Dewey, linked science to a liberal, social democratic political orientation (Howard, 2003: p. 25). Through a reworked conception of knowledge as inter-subjective, Dewey blurred the dividing line between fact and value. As "organized social intelligence", science, stated Dewey, "is inherently an instrument of critically determining what is good and bad in the way of acceptance and rejection" (Dewey, 1929: p. 423 in Howard, 2003: p. 52). Following this argument, in one of his more "radical" moments, Dewey used science to defend cooperative control of the "forces of productivity" (Dewey, 1935: pp. 54-55 in Howard, 2003: p. 52).

Howard (2003: pp. 72-73) reflects on the factors involved in the shift from Dewey's politically engaged version of science to a politically neutral version, which he describes as a retreat from the "realm of value". He acknowledges the Cold War climate and the rise of McCarthyism in the 1950s as important factors affecting this trend. He also suggests that the focus on the nuclear deterrent in geopolitics gave added luster to physical sciences, with the human sciences "trying hurriedly to bring their methodologies up to" their "high standard" (Howard, 2003: p. 73). For example, there was growing interest in professionalizing the study of education, a search for "a distinct science of the field" (Lagemann, 1989: p. 295; emphasis added). ${ }^{2}$

Alongside professionalization and the other factors contributing to this "turn to the right", Howard (2003: p. 71, p. 74; emphasis added) emphasizes the willingness of "even the most explicitly political left-wing Vienna Circle logical empiricists [recalling Neurath] and Deweyan pragmatists" to march "under the banner of objective science". Howard's suggestion is that the unwavering commitment to objective science and fixed "problems", even among those on the "left", allowed a technocratic version of problem-solving to gain purchase. ${ }^{3}$ The contribution of "the cognitive turn" to these developments is considered briefly in the next section.

\subsection{The Cognitive Revolution}

As mentioned above, the second model of problem-solving knowledge, charac${ }^{2}$ Howard (2003: pp. 72-73) argues that the "logic of professionalization" makes it easier to exclude "those whose opinions stray too much from the core commitments that define community membership". As an illustration, the drive to establish professional status in the philosophy of science led to a dramatic narrowing of the topics addressed in the journal Philosophy of Science: "One notices the almost total and almost immediate disappearance of at least four genres of literature that had been common in the journal before 1959"-on science and values; on matters explicitly on political ideology; on science planning and science policy; and on the sociology of knowledge.

${ }^{3}$ Some contemporary theorists who describe themselves as pragmatists and who draw on Dewey leave themselves open to technocratic problem-solving because of their unquestioned acceptance of "problems" as pre-existent starting points for analysis and an unwavering belief in scientific method (see Biesta, 2007; Rorty, 1996; Sanderson, 2009). 
terized as "expert-led" and "technocratic", is linked to behaviouralism and cognitivism. Cognitivism demands particular attention, given current developments in problem-solving knowledge in PISA and PIAAC, the focus in Section 4 of the article.

The economist and political scientist, Herbert A. Simon, is a leading exponent of the "cognitive turn". He is a central figure in the development of artificial intelligence, information processing, decision-making theory and problem-solving. His work on "bounded rationality" (Simon, 1972) is regularly quoted in public policy texts (Simon et al., 1992). Both on his own and with others, including Alan Newell and the critical realist, Ray Bhaksar, Simon contributed important publications on human problem-solving (see Newell et al., 1958; Newell \& Simon, 1972; Bhaksar \& Simon, 1977; Simon, 1978).

Simon (1978) provides the underlying arguments for the need to develop "cognitive skills"-a pervasive narrative in PISA and other contemporary problem-solving initiatives, as elaborated in the next section. The focus in this approach to human cognition is on the mind's ability to manipulate symbols as performed in computer simulations. The goal of learning is to find "expert" rules that solve a problem with less search effort and greater effectiveness than "novice" rules (Bredo, 1997: p. 29). As mentioned earlier, such an approach requires fixed problems against which to test the process of cognitive learning and produces a "physically passive approach to learning" (Bredo, 1997: p. 30). The predominance of these views is illustrated in contemporary knowledge-making practices, reflecting specifically on "skill"-testing international education regimes.

\section{Problem-Solving Knowledge in Contemporary International Organizations (Practices of Functioning)}

Returning briefly to the three interconnected domains within which a problem-solving knowledge operates-background knowledge (savoir), disciplines (connaissances) and governmental technologies-this section of the article examines technologies that elucidate how problem-solving knowledge functions in twenty-first century western societies and international organizations.

In governmentality theory, technologies comprise the means by which governing becomes practicable. They encompass specific instruments of governing, together with the interdependencies surrounding these instruments. They can take the form of league tables, performance data, case management, and the vast array of programs and policies enabling various authorities to "shape, normalize and instrumentalize" the conduct of individuals and groups (Miller \& Rose, 1990: p. 8; Inda, 2005: p. 9). Studying technologies broadens the scope of political analysis to encompass power relations among political subjects, forms of knowledge and expertise (see Hogsbro \& Shaw, 2017: p. 149).

Evidence-based policy is a technology in this sense, as is lifelong learning (Fejes \& Nicoll, 2008). Examples of specific instruments, with explicit links to prob- 
lem-solving knowledge, include the European Commission's (2018) website Solvit, offering "solutions to problems with your EU rights" (http://ec.europa.eu/solvit/), and the EC's CEDEFOP Glossary, which defines "skill" as "the ability to perform tasks and solve problems" (European Commission, 2008: p. 164).

Two instruments-the OECD international "skills"-testing programs, PISA and PIAAC-serve to illustrate the institutionalization and functioning of contemporary problem-solving knowledge. Beginning in 2000, PISA is a triennial international survey that aims to evaluate education systems worldwide by testing the "skills" and knowledge of 15-year-old students. From its inception it examined literacy, numeracy, and cross-curricular "competencies", including ICT and problem-solving "skills". An intensifying interest in the latter is signaled in the emphasis on problem-solving in the 2015 PISA assessment (OECD, 2017).

PIAAC collects data on adult "skills", including literacy, numeracy and problem-solving in technology-rich environments (PS-TRE). There were three rounds of data collection between 2011 and 2017, with a second cycle planned for 2021-22. American Educational Testing Services (ETS), which overseas management of PISA, produced a volume in 2015, entitled America's Skills Challenge: Millennials and the Future (Coley, Goodman, \& Sands, 2015). This volume reported on the literacy, numeracy and problem-solving "skills" of 16- to 34 -year-olds in 22 countries using data from PIAAC. While these programs have attracted a good deal of critical attention (see Normand, 2016; Gorur, 2011, 2016; Sellar \& Lingard, 2014; Shaw \& Child, 2017), to date no one has noted the significant role played by problem-solving knowledge within these programs, and the political implications that accompany its functioning-tasks undertaken in this section of the article.

The OECD defines problem-solving as "the capacity to engage in cognitive processing to understand and resolve problem situations where a method of solution is not immediately obvious." It includes "the willingness to engage with such situations in order to achieve one's potential as a constructive and reflective citizen"-a point taken up later in the article (OECD, 2014a). Problem-solving is spoken of as both a method-a scientific problem-solving method-and a cognitive ability. The focus is clearly on what is measurable, an example of "governing by numbers" (Miller, 2001; see also Grimaldi, 2020). In the Foreword to The Nature of Problem Solving (Csapó \& Funke, 2017: p. 4), Schelicher, OECD Director for Education and Skills, explains why PISA measures students' problem-solving abilities: "because educators have few reliable metrics to observe the problem-solving skills of their students-and what doesn't get assessed doesn't get done". 4

The declared need for problem-solving abilities and problem-solving metrics ${ }^{4}$ Steven Lewis (2017: p. 292); emphasis in original) points out that governing by numbers is supplemented with examples of best practice in the Pisa for Schools reports: "This emphasises the significance to PISA for Schools of governance by numbers and examples, where the 'hard' evidence of numerical data authoritatively validates the 'soft' examples of best practice". 
is tied to labour-market requirements. The Foreword to the summary of PISA 2012 results on "Creative Problem Solving" made this connection explicit:

highly skilled adults are twice as likely to be employed and almost three times more likely to earn an above-median salary than poorly skilled adults.

(OECD, 2014b: p. 3; emphasis added)

Problem-solving is designated a " $21^{\text {st }}$ Century skill" or "competency"-the type of "skill" that is increasingly required by employers given the shift from routine (read automated) to non-routine tasks (OECD, 2014b: p. 13, p. 26, p. 73).

To fulfill this market need, subjects have to become adaptable and creative. "Creative" problem-solving refers to an ability to apply problem-solving as a method of analysis to novel situations. Students are to take charge of assigned "problems" and to engage in lifelong learning to assure their flexibility in an uncertain world-described as a VUCA world (management-speak for a world that is Volatile, Uncertain, Complex and Ambiguous) (OECD, 2014b: p. 26).

A 2017 contribution from Dirk Van Damme, Head of the Innovation and Measuring Progress Division, Directorate for Education and Skills, indicates the instrumental logic at work in OECD thinking. His brief article is entitled intriguingly: "Does the world need people who understand problems, or who can solve them?" Understanding, it appears, is unnecessary if a person can figure out "what works". There is a clear link here to evidence-based policy and its problem-solving logic, mentioned earlier. Van Damme (2017) concludes: "it is not difficult to predict that tomorrow's world will need more problem solvers". ${ }^{5}$

The OECD has developed a conceptual architecture around "problems" and "problem-solving", which forms part of a vast web of interrelated concepts, including "wellbeing" (OECD, 2015) and "human capital" (Morgan \& Volante, 2016). The list below is illustrative rather than comprehensive:

Complex and simple problems (and Complex Problem Solving-CPS-see Greiff \& Fischer, 2013)

Creative Problem Solving

Well-structured problems and poorly-structured problems

Real-world problems versus laboratory experiments

Expert versus novice problem solving

Domain-specific versus domain-general problem solving

Interactive versus static problem solving

Dynamic problem solving

Adaptive Problem Solving (APS) (see Greiff et al., 2017)

Collaborative Problem Solving (CPS) (Shaw \& Child, 2017)

Problem Solving in Technology-Rich Environments (PS-TRE)

${ }^{5}$ On a recent visit to Roskilde University (8-9 October 2018) a banner displayed at the nearby train station declared: "Welcome to more than 1800 new problemsolvers" ["Velkommen til mere end 1800 nye problemløsere".] The author wishes to thank Agnete Meldgaard Hansen for bringing the banner to her attention. The banner signifies both the pervasiveness and presumed innocence of problem-solving knowledge, premises put under critical scrutiny in this article. 
Computer-Supported Collaborative Learning (CSCL) (Stahl, 2015)

"Problems" in OECD problem-solving approaches are conceptualized as pre-existent states that prompt analysis, as "problems-that-exist". For example, the PIAAC Conceptual Framework locates as a starting point for analysis "the problem statement" - the "elements of a situation that trigger and condition problem solving" (PIAAC Expert Group, 2009: p. 11).

Collaborative Problem Solving (CPS), a recent addition to the OECD lexicon (OECD, 2017), marks an attempt to move beyond earlier renditions of problem-solving that focused on individuals. The stated goal of collaborative problem-solving is to "construct and maintain a shared conception of a problem" (Roschelle \& Teasley, 1995: p. 70). "Problems" therefore remain exogenous to the policy process and taken-for-granted starting points for analysis. Moreover, the emphasis on producing a "shared conception of a problem" reduces the space for dissensus, a point returned to later. Finally, while the move towards interaction appears a significant advance on solitary problem-solving, it is important to note that the interaction-the collaboration-takes place with computers, called "conversational agents", a development that has generated a new industry-CSCL (Computer-Supported Collaborative Learning) (Lajoie \& Derry, 2013; Stahl, 2015).

Adaptive Problem Solving (APS), another recent development, is clearly intended to challenge a view of learners as static and passive. There are moves to incorporate a measure of APS in the second cycle of PIAAC (Greiff et al., 2017). The emphasis in "adaptive problem solving" is on the need for problem solvers to revisit and revise the initial problem when there is new information. While the "problem" is thus open to modification, the goal is to gain accurate comprehension of a "problem-that-exists", taken to be independent from the processes of examination. As Herbert A. Simon (1973: p. 195) puts it, "the problem solver is faced at each moment with a well structured problem, but one that changes from moment to moment."

Alongside the increased focus on problem-solving in these programs sits an intensified interest in "cognitive abilities". In OECD publications problem-solving is commonly referred to as a "higher order" cognitive skill associated with the brain's "executive function". The Expert Group's Conceptual Framework for PS-TRE stipulates that: "The ability to solve problems is considered one of the most complex and sophisticated aspects of human cognition" (PIAAC Expert Group, 2009: p. 7). Newell and Simon's 1972 book, Human Problem Solving, is offered as a reference (PIAAC Expert Group, 2009). The Framework specifies that: "The cognitive dimensions of problem solving are considered the central object of the assessment" (2009: 15). "Cognitive dimensions" of problem-solving involve "the mental structures by which a person actually performs problem solving". These include: "goal setting and monitoring progress; planning; locating; selecting and evaluating information; and organizing and transforming information" (PIAAC Expert Group, 2009: p. 11).

The turn to "cognitive abilities", with problem-solving a key ability, marks a 
worrisome trend towards forms of determinism in ranking and evaluating human worth. The question of whether cognitive abilities are innate or shaped environmentally is seldom addressed directly, and it is left to the researcher to hunt down positions on this contentious issue. It is unusual to find an explicit stance such as this unequivocal declaration in Greiff et al. (2017; emphasis added), in an OECD Working Paper:

Most of these fundamental cognitive processes are not generally considered malleable (or at least very difficult to do so) and are expected to affect success in answering numeracy and literacy items as well as problem-solving tasks.

The American National Research Council (Pellegrino \& Hilton, 2012: Sum 3 fn 1) argues that the "common view" is that cognitive abilities are "fixed traits", although the Council itself declares them "malleable dimensions of human behavior that can change in response to educational interventions and life experiences".

In PISA the clear impression is that some students are (simply) good at problem-solving while others are less successful. The scoring system records six levels of proficiency, with detailed descriptions of what students "can typically do" (OECD, 2014b: p. 57). Students with high scores become "top performers" and the implications for their future are clear:

As machines and computers are increasingly replacing humans for performing routine tasks, highly skilled workers, who are capable of applying their unique skills flexibly in a variety of contexts, regulating their own learning, and handling novel situations, are more and more in demand. (OECD, 2014b: p. 60; emphasis added)

Meanwhile, important links are drawn between "cognitive abilities" and economic performance, with explicit policy implications. The OECD (2010: p. 3) uses economic modeling produced by Eric Hanushek et al. (2015) "to relate cognitive skills-as measured by PISA and other international instruments-to economic growth". Based on PIAAC results, Hanushek et al. (2015: p. 104) develop "estimates of the earnings returns to cognitive skills across the entire labor force for 23 countries". Leaving causal explanations ambiguous, their study concludes: "Intriguingly, returns to [cognitive] skills are systematically lower in countries with higher union density, stricter employment protection legislation, and larger public sectors" (Hanushek at el., 2015: p. 103, p. 123). The political implications of this conclusion receive no further comment.

Nikolas Rose (2004) suggests that there are signs in current sociopolitical relations that we are moving from a psychological view of the subject to a somatic view, with the latter focusing on biological brain and body functions. The privileging of cognitive skills and of problem-solving as a key part of this "skill set", observed in PISA and PIAAC programs, supports this proposition. However, a further development needs to be taken into account. Accompanying the empha- 
sis on cognitive abilities in PISA and PIAAC tests are questions that target non-cognitive "characteristics", specifically "motivation" and a "willingness to engage" with "problem situations" (see above in OECD definition of problem-solving; OECD, 2014a). Through the focus on "motivation", a moralizing element appears in problem-solving knowledge, a moralizing element that relies upon and produces "motivation" as an individual trait (Ahl, 2006).

For example, 2012 PISA results link "high achievement in mathematics" to "high levels on the index of openness to problem solving, a measure of general drive and motivation" (OECD, 2014b: p. 111; emphasis added). The National Research Council, quoted earlier to reference their less deterministic view on “cognitive abilities", shares the OECD's judgment on “intrapersonal dimensions of learning". Their "cluster" of " $21^{\text {st }}$ century competencies" includes:

Work Ethic (aligned with the personality factor of Conscientiousness), including such skills as initiative and self direction, responsibility, Type 1 self-regulation (metacognition, including forethought, performance, and self-reflection), and perseverance. (Pellegrino \& Hilton, 2012: Sum 3)

In PISA these "personality factors" become linked directly to presumed cognitive ability:

Everything in the PISA data indicates that high levels of perseverance and openness to problem solving, work as a catalyst for ever-higher performance among the most talented students. (OECD, 2014b: p. 111; emphasis added)

This reference to "most talented students" implies the existence of a natural pool of "talent". Moreover, the phrasing also suggests that only the "most talented" will benefit from "perseverance", leaving those "naturally" "less talented" stuck in a category where opportunities to succeed are few. Hence, both "biological" mental capacity and "personal" psychological "traits" are subject to increasing scrutiny and judgment (see Sellar \& Lingard, 2014).

As with problem-solving knowledge generally, there is no space in PISA or PIAAC testing regimes for students or adults to question the "problems" set for solving. There are numerous references to the need to use "real-world problems" in order to "engage" students (OECD, 2014b). Common suggestions include a new type of vending machine or an MP3 player that refuses to work properly (OECD, 2014b). Some reformers, highly critical of PISA programs, make children's participation a core element of problem-solving (Richardson et al., 2017; Zhao, 2017). However, so long as students are expected to memorize and apply an established and generally accepted scientific problem-solving process to "given" problems, they are constituted as passive. As Popkewitz (2004: p. 25) argues,

the problem-solving strategies taught in school subjects may actually reduce the spaces that are open for participation and action because scientific expertise is viewed as constituting social realities for children to work on. 
It could, of course, be argued that PISA is irrelevant, that it has no impact on local and national schooling practices. There are, however, many examples where changes in school organization and curricula have followed directly from "poor" performance in international league tables (Cresswell, 2016). Hence, it becomes important to consider how PISA establishes its authority, and the implications for researchers.

\subsection{The Investment in "Problems"}

On this issue, it is clear that many academics have benefitted through investing their experience in European or international educational programs, illustrating a mutual interdependence of expertise and "the state" (Foucault, 1991b; Johnson, 1995; Normand, 2016: pp. 12-13). Waldow (2009: p. 481) provides an example: "The enormous resonance of the PISA debate has led to a massive expansion of empirical educational research of the PISA-type in Germany". As Gorur (2016) argues, it is becoming increasingly difficult not to "see like PISA".

The investment in PISA-associated research illustrates a larger research phenomenon, aptly described as an "investment in problems". The argument here is that "problems" as self-evident referents, as "problems-that-exist", become the bread and butter of many, if not most, researchers (see Pienaar et al., 2018: pp. 14-16). In a study of alcohol and other drug policy, for example, Bacchi (2015b) found that the notion of "alcohol problems" emerged as a category of analysis in large part due to researchers' concern to establish credibility for their work. Writing about $20^{\text {th }}$ century alcohol and drug policy research, Sulkunen and Warsell (2012: p. 219) explain that, "Because, with effort and ingenuity, 'problems' can be counted, they fit the positivist paradigm that characterized the new public health endeavor at the time". This symbiosis between "problems" and research helps to explain the popularity of evidence-based initiatives, problem-solving methodologies and, relatedly, the prevailing positivist research paradigm. Problem-solving knowledge therefore plays a central role, not only in the making of school students, but also in the making of university academics and research paradigms (see Normand, 2016).

Attempts to disrupt problem-solving knowledge come from several directions. Section 5 of the article considers briefly the critical potential of three important forms of contestation: first, interpretive challenges to "given" problems; second, philosophical challenges to a problem-solving model of the human condition; and third Foucault-influenced poststructural analysis, including WPR (Bacchi, 2009; Bacchi \& Goodwin, 2016).

\section{Contesting Problem-Solving Knowledge}

It is important to recognize the challenge posed to technocratic problem-solving by interpretivists, including those mentioned previously who investigate competing framings of "problems" and who promote a dialogue-based, deliberative vision of democracy. The recent edited collection by Cruickshank and Sassower 
(2017) entitled Democratic Problem Solving. Dialogues in Social Epistemology provides a useful example of this position. The argument in this volume, put briefly, is that problem-solving can be redeemed, that it can lose its "narrowly scientistic connotations" and become connected with "permanent open-ended critique" (Kemp, 2017: p. 30). The stated objective is to change "the terms of reference that currently frame problems, to find more useful problems" (Cruickshank \& Sassower, 2017: xii; emphasis added). Despite the valuable recognition of the need to prevent premature closure on important debates, the suggestion that it is possible to find "more useful problems" indicates that democratic problem-solving conceptualizes problems as (simply) "things-that-exist", limiting the space for contestation.

The prominent Harvard philosopher, Stanley Cavell, offers a second form of disruption, questioning the implications of problem-solving knowledge for the human condition. In interview Cavell declares:

I don't believe that human existence is just one damn problem after another. And in reading Dewey, who was my first love in philosophy, you can sort of get that idea: "You have a problem-well, let's see what the problem is, and we solve it, and then we go on." "Yes, I have a problem: I'm going to die, so let's solve that for me!” (Richardson, 2011; emphasis in original)

Cavell is concerned that the "depth of psychoanalytic discovery" is missing from Dewey's text (Cavell, 1990: p. 13 in Saito \& Standish, 2009: p. 161). In his view, "mourning," "suffering," "patience," and "passion" are "more representative elements of human experience, at odds with the active tendency in Dewey's science" (Cavell, 1998: p. 73, p. 76, p. 78 in Saito \& Standish, 2009: p. 158). For Cavell, the "sense of the riven" is missing in Dewey's "ameliorative response to the tragic" (Saito \& Standish, 2009: p. 162). Looking to political implications, Saito and Standish (2009: p. 57) note that the focus on amelioration in Dewey-influenced pragmatism produces a desire for consensus, leaving insufficient space for dissensus, a theme noted earlier in OECD Collaborative Problem Solving.

The third form of disruption is mounted in poststructural critical analysis, as illustrated in this article. In this view interpretivism is restricted in its critical ability through its continued acceptance of "problems-that-exist". There is also hesitation to endorse grand claims about the impact of problem-solving on the human condition, as per Cavell. The grounds for staking out a position critical of problem-solving include the "turn to cognition" with its associated moralism and the way it is being deployed to divide "citizens" into successful and unsuccessful categories. More broadly, treating "problems" as self-evident referents is considered to be depoliticizing, undermining the ability to recognize how governing takes place through problematization-through the shaping of "problems" as particular sorts of problems.

The education researcher, Popkewitz (2004), makes the point that critical 
thought involves being able to question the premises of taken-for-granted belief systems. He argues that for students to become critical thinkers, they need to be able to ask questions about assumed knowledges, including the scientific method. The Foucault-influenced WPR ("What's the Problem Represented to be?") analytic strategy, introduced earlier, encourages precisely the kind of critical thought Popkewitz has in mind. It challenges the assumed givenness of "problems" and provides a way to interrogate their premises and the knowledges upon which they rely, potentially engaging students in "a process of open problematisation" (see Farrugia et al., 2018 for an example of this form of application of WPR).

At the same time there is a need to acknowledge that we, as researchers, may well be engaged in producing "truths" that can have deleterious implications through our "investment in problems" (see discussion in Section 4.1). The task, as Chantal Mouffe (1996: p. 6) describes it, is to avoid complacency. Foucault (2000) calls for an "ethic of discomfort". In tune with these interventions, the WPR approach includes, as Step 7, self-problematization (Bacchi \& Goodwin, 2016: p. 20). In self-problematization, researchers are exhorted to apply the WPR questions to their own proposals and proposed "solutions". The goal is to open up their own problematizations to critical scrutiny as a form of "self-deconstructing" analysis (Chia, 1996: p. 49).

\section{Conclusion}

This article develops the argument that a particular approach to thinking, problem-solving, dominates the current intellectual and policy landscape. An abbreviated genealogy examines the operation of this problem-solving knowledge in several fields, including mathematics, science studies, public policy and education studies. This brief survey highlights the twists and turns leading to the current dominance of a technocratic problem-solving model. The article proceeds to examine how this problem-solving knowledge functions in the important international "skills"-testing programs, PISA and PIAAC. It emphasizes how these programs produce passive and divided subjects, and reinforce a positivist paradigm in research approaches, while drawing attention to ways of contesting these views.

The paper does not presume that all those who work with specific incarnations of problem-solving knowledge are somehow misguided. Nor does it suggest that problem-solving knowledge can be dethroned from its epistemological pedestal. Still, the case is made that it is politically exigent to reflect on how problem-solving knowledge has come to be taken-for-granted as "truth" and on how it operates to limit political debate and to regulate political subjects. To this end it calls for refocusing attention on how governing takes place through the production of "problems" as particular sorts of problem-through problematization-creating space to disrupt the near consensus regarding the benefits of problem-solving. 


\section{Conflicts of Interest}

The author declares no conflicts of interest regarding the publication of this paper.

\section{References}

Ahl, H. (2006). Motivation in Adult Education: A Problem Solver or a Euphemism for Direction and Control? International Journal of Lifelong Education, 25, 385-405. https://doi.org/10.1080/02601370600772384

Bacchi, C. (2009). Analysing Policy: What's the Problem Represented to Be? Frenchs Forest: Pearson Education.

Bacchi, C. (2015a). The Turn to Problematization: Political Implications of Contrasting Interpretive and Poststructural Adaptations. Open Journal of Political Science, 5, 1-12. https://doi.org/10.4236/ojps.2015.51001

Bacchi, C. (2015b). Problematizations in Alcohol Policy: WHO's “Alcohol Problems”. Contemporary Drug Problems, 42, 130-147. https://doi.org/10.1177/0091450915576116

Bacchi, C., \& Bonham, J. (2014). Reclaiming Discursive Practices as an Analytic Focus: Political Implications. Foucault Studies, 17, 173-192. https://doi.org/10.22439/fs.v0i17.4298

Bacchi, C., \& Goodwin, S. (2016). Poststructural Policy Analysis: A Guide to Practice. New York: Palgrave Macmillan. https://doi.org/10.1057/978-1-137-52546-8

Bardach, E. (1981). Problems of Problem Definition in Policy Analysis. In J. Crecine (Ed.), Research in Public Policy Analysis and Management (Vol. 1, pp. 161-171). Greenwich, CT: JAI Press.

Bhaksar, R., \& Simon, H. A. (1977). Problem Solving in Semantically Rich Domains: An Example from Engineering Thermodynamics. Cognitive Science, 1, 193-215. https://doi.org/10.1207/s15516709cog0102_3

Biesta, G. (2007). Why "What Works" Won't Work: Evidence-Based Practice and the Democratic Deficit in Educational Research. Educational Theory, 57, 1-22. https://doi.org/10.1111/j.1741-5446.2006.00241.x

Bredo, E. (1997). The Social Construction of Learning. In G. D. Phye (Ed.), Handbook of Academic Learning: Construction of Knowledge (pp. 3-45). San Diego, CA: Academic Press. https://doi.org/10.1016/B978-012554255-5/50002-8

Callon, M. (1980). Struggles and Negotiations to Define What Is Problematic and What Is Not: The Sociologic Translation. In K. D. Knorr, R. Krohn, \& R. Whitley (Eds.), The Social Process of Scientific Investigation. Sociology of the Sciences: Yearbook (pp. 197-221). Dordrecht, Holland: D. Reidel Pub Co. https://doi.org/10.1007/978-94-009-9109-5_8

Cavell, S. (1990). Conditions Handsome and Unhandsome: The Constitution of Emersonian Perfectionism. La Salle, IL: Open Court.

Cavell, S. (1998). What's the Use of Calling Emerson a Pragmatist? In M. Dickstein (Ed.), The Revival of Pragmatism: New Essays on Social Thought, Law, and Culture (pp. 72-80). Durham, NC: Duke University Press. https://doi.org/10.1215/9780822382522-006

Chia, R. (1996). The Problem of Reflexivity in Organizational Research: Towards a Postmodern Science of Organization. Organization, 3, 31-59. https://doi.org/10.1177/135050849631003

Coley, R. J., Goodman, M. J., \& Sands, A. M. (2015). America’s Skills Challenge Millen- 
nials and the Future. Princeton, NJ: Educational Testing Services.

Cresswell, J. (2016). System-Level Assessment and Educational Policy. http://research.acer.edu.au/assessgems/10

Cruickshank, J., \& Sassower, R. (Eds.) (2017). Democratic Problem-Solving: Dialogues in Social Epistemology. London: Rowman \& Littlefield.

Csapó, B., \& Funke, J. (Eds.) (2017). The Nature of Problem Solving: Using Research to Inspire 21st Century Learning. Centre for Educational Research and Innovation. Paris: OECD Publishing. https://doi.org/10.1787/9789264273955-en

Dery, D. (1984). Problem Definition in Policy Analysis. Lawrence, KS: University Press of Kansas.

Dewey, J. (1910). How We Think. Boston, MA: D. C. Heath and Company. https://doi.org/10.1037/10903-000

Dewey, J. (1929). Experience and Nature (2nd ed.). New York: W W Norton \& Co. https://doi.org/10.1037/13377-000

Dewey, J. (1935). Liberalism and Social Action. New York: G. P. Putnam’s Sons.

Dewey, J. (1938). Logic: The Theory of Inquiry. New York: Holt, Rinehart and Winston.

Dimock, M. (1958). A Philosophy of Administration. New York: Harper.

Dossey, J. A. (2017). Problem Solving from a Mathematical Standpoint. In B. Csapó, \& J. Funke (Eds.), The Nature of Problem Solving: Using Research to Inspire 21st Century Learning (pp. 59-72). Paris: OECD Publishing.

Entman, R. M. (1993). Framing: Toward a Clarification of a Fractured Paradigm. Journal of Communication, 43, 51-58. https://doi.org/10.1111/j.1460-2466.1993.tb01304.x

European Commission (2008). Terminology of European Education and Training Policy. A Selection of $100 \mathrm{Key}$ Terms. CEDEFOP [European Centre for the Development of Vocational Training]. Luxembourg: Office for Official Publications of the European Communities.

European Commission (2018). SOLVIT. http://ec.europa.eu/solvit/

Farrugia, A., Seear, K., \& Fraser, S. (2018). Authentic Advice for Authentic Problems? Legal Information in Australian Classroom Drug Education. Addiction Research \& Theory, 26, 193-204. https://doi.org/10.1080/16066359.2017.1343823

Fejes, A., \& Nicoll, K. (Eds.) (2008). Foucault and Lifelong Learning: Governing the Subject. London: Routledge. https://doi.org/10.4324/9780203933411

Fischer, F. (2000). Citizens, Experts, and the Environment: The Politics of Local Knowledge. Durham \& London: Duke University Press. https://doi.org/10.1215/9780822380283

Fischer, F. (2003). Reframing Public Policy: Discursive Politics and Deliberative Practices. Oxford: Oxford University Press.

Foucault M. (2000). For an Ethics of Discomfort. In J. D. Faubion (Ed.), Power: Essential Works of Foucault, 1954-1984 (Volume III, pp. 443-448). New York: The New Press.

Foucault, M. (1972). The Archaeology of Knowledge, and the Discourse on Language (A. M. Sheridan Smith, Trans.). New York: Pantheon Books.

Foucault, M. (1991a) [1968]. Politics and the Study of Discourse. In G. Burchell, C. Gordon, \& P. Miller (Eds.), The Foucault Effect: Studies in Governmentality (pp. 53-72). Chicago, IL: University of Chicago Press.

Foucault, M. (1991b) [1978]. Governmentality. In G. Burchell, C. Gordon, \& P. Miller (Eds.), The Foucault Effect: Studies in Governmentality (pp. 87-104). Chicago, IL: University of Chicago Press. 
Gorur, R. (2011). ANT on the PISA Trail: Following the Statistical Pursuit of Certainty. Educational Philosophy and Theory, 43, 76-93.

https://doi.org/10.1111/j.1469-5812.2009.00612.x

Gorur, R. (2016). Seeing Like PISA: A Cautionary Tale about the Performativity of International Assessments. European Educational Research Journal, 15, 598-616. https://doi.org/10.1177/1474904116658299

Gottweis, H. (1998). Governing Molecules: The Discursive Politics of Genetic Engineering in Europe and the United States. Cambridge, MA: MIT Press. https://doi.org/10.7551/mitpress/3334.001.0001

Gottweis, H. (2003). Theoretical Strategies of Poststructuralist Policy Analysis: Towards an Analytics of Government. In M. Hajer, \& H. Wagenaar (Eds.), Deliberative Policy Analysis: Understanding Governance in the Network Society (pp. 247-265). Cambridge: Cambridge University Press. https://doi.org/10.1017/CBO9780511490934.011

Greiff, S., \& Fischer, A. (2013). Measuring Complex Problem Solving: An Educational Application of Psychological Theories. Journal for Educational Research Online, 5, 38-58.

Greiff, S., Scheiter, K., Scherer, R., Borgonovi, F., Britt, A., Graesser, A., Kitajima, M., \& Rouet, J.-F. (2017). Adaptive Problem Solving: Moving towards a New Assessment Domain in the Second Cycle of PIAAC. OECD Education Working Papers, No. 156, Paris: OECD Publishing.

Grimaldi, E. (2020). An Archaeology of Educational Evaluation: Epistemological Spaces and Political Paradoxes. London: Routledge. https://doi.org/10.4324/9780203704363

Hajer, M., \& Versteeg, W. (2005). A Decade of Discourse Analysis of Environmental Politics: Achievements, Challenges, Perspectives. Journal of Environmental Policy \& Planning, 7, 175-184. https://doi.org/10.1080/15239080500339646

Hajer, M., \& Versteeg, W. (2011). Discursive Policy Analysis. In B. Badie, D. Berg-Scholosser, \& L. Morlino (Eds.), International Encyclopedia of Political Science (pp. 686-688). Thousand Oaks, CA: Sage.

Hanushek, E. A., Schwerdt, G., Wiederhold, S., \& Woessmann, L. (2015). Returns to Skills around the World: Evidence from PIAAC. European Economic Review, 73, 103-130. https://doi.org/10.1016/j.euroecorev.2014.10.006

Head, B. (2008). Wicked Problems in Public Policy. Public Policy, 3, 101-118.

Head, B. (2018). Forty Years of Wicked Problems Literature: Forging Closer Links to Policy Studies. Policy \& Society, 38, 180-197.

https://doi.org/10.1080/14494035.2018.1488797

Hogsbro, K., \& Shaw, I. (2017). Social Work and Research in Advanced Welfare States. London: Routledge. https://doi.org/10.4324/9781315279015

Howard, D. (2003). Two Left Turns Make a Right: On the Curious Political Career of North American Philosophy of Science at Midcentury. In G. L. Hardcastle, \& W. W. Richardson (Eds.), Logical Empiricism in North America (pp. 25-93). Minneapolis, MN: University of Minnesota Press.

Howlett, M. (2010). Designing Public Policies: Principles and Instruments. New York: Routledge.

Inda, J. X. (2005). Analytics of the Modern: An Introduction. In J. X. Inda (Ed.), Anthropologies of Modernity. Foucault, Governmentality, and Life Politics (pp. 1-20). Malden, MA: Blackwell. https://doi.org/10.1002/9780470775875.ch

Johnson, T. (1995). Governmentality and the Institutionalization of Expertise. In T. Johnson (Ed.), Health Professions and the State in Europe (pp. 7-24). London: Rout- 
ledge.

Kemp, S. (2017). On Popper, Problems and Problem-Solving: A Review of Cruickshank and Sassower's Democratic Problem-Solving. Social Epistemology Review and Reply Collective, 6, 27-34.

Krohn, R. (1980). Introduction: Toward the Empirical Study of Scientific Practice. In K. D. Knorr, R. Krohn, \& R. Whitley (Eds.), The Social Process of Scientific Investigation (pp. vii-xv). Sociology of the Sciences: Yearbook. Dordrecht, Holland: D. Reidel Pub Co.

Kurze, K., \& Lenschow, A. (2018). Horizontal Policy Coherence Starts with Problem Definition: Unpacking the EU Integrated Energy-Climate Approach. Environmental Policy and Governance, 28, 329-338. https://doi.org/10.1002/eet.1819

Lagemann, E. C. (1989). The Plural Worlds of Educational Research. History of Education Quarterly, 29, 185-214. https://doi.org/10.2307/368309

Lajoie, S. P., \& Derry, S. J. (Eds.) (2013). Computers as Cognitive Tools. New York: Routledge. https://doi.org/10.4324/9780203052594

Lasswell, H. D. (1951). The Policy Orientation. In D. Lerner, \& H.D. Lasswell (Eds.), The Policy Sciences: Recent Developments in Scope and Method (pp. 3-15). Stanford, CA: Stanford University Press.

Latour, B. (1980). Is It Possible to Reconstruct the Research Process? Sociology of a Brain Peptide. In K. D. Knorr, R. Krohn, \& R. Whitley (Eds.), The Social Process of Scientific Investigation (pp. 53-73). Sociology of the Sciences: Yearbook. Dordrecht, Holland: D. Reidel Pub Co. https://doi.org/10.1007/978-94-009-9109-5_3

Lave, J. (2009) [1988]. Cognition in Practice: Mind, Mathematics and Culture in Everyday Life. Cambridge: Cambridge University Press. https://doi.org/10.1017/CBO9780511609268

Law, J. (2009). The Greer-Bush Test: On Politics in STS, Version of 23rd December 2009. http://heterogeneities.net/publications/Law2009TheGreer-BushTest.pdf

Lemke, T. (2007). An Indigestible Meal? Foucault, Governmentality and State Theory. Distinktion: Journal of Social Theory, 8, 43-64. https://doi.org/10.1080/1600910X.2007.9672946

Lewis, S. (2017). Governing Schooling through "What Works": The OECD's PISA for Schools. Journal of Education Policy, 32, 281-302. https://doi.org/10.1080/02680939.2016.1252855

Miller, P. (2001). Governing by Numbers: Why Calculative Practices Matter. Social Research, 68, 379-396.

Miller, P., \& Rose, N. (1990). Governing Economic Life. Economy and Society, 19, 1-31. https://doi.org/10.1080/03085149000000001

Morgan, C., \& Volante, L. (2016). A Review of the Organisation for Economic Cooperation and Development's International Education Surveys: Governance, Human Capital Discourses, and Policy Debates. Policy Futures in Education, 14, 775-792. https://doi.org/10.1177/1478210316652024

Mouffe, C. (1996). Deconstruction, Pragmatism and the Politics of Democracy. In C. Mouffe (Ed.), Deconstruction and Pragmatism: Simon Critchley, Jacques Derrida, Ernesto Laclau and Richard Rorty (pp. 1-12). New York: Routledge.

Neurath, O., Hahn, H., \& Carnap, R. (1929). Wissenschaftliche Weltauffassung: Der Wiener Kreis. Vienna: Artur Wolf. Page numbers and translations from "The Scientific Conception of the World: The Vienna Circle" in O. Neurath, Empiricism and Sociolo$g y$ (pp. 299-318). Dordrecht and Boston: Reidel, 1973. 
Newell, A., \& Simon, H. A. (1972). Human Problem Solving. Englewood Cliffs, NJ: Prentice-Hall.

Newell, A., Shaw, J. C., \& Simon, H. A. (1958). Elements of a Theory of Human Problem Solving. Psychological Review, 65, 157-166. https://doi.org/10.1037/h0048495

Normand, R. (2016). The Changing Epistemic Governance of European Education: The Fabrication of the Homo Academicus Europeanus? Switzerland: Springer Nature.

OECD (2010). The High Cost of Low Educational Performance: The Long-Run Economic Impact of Improving PISA Outcomes. Programme for International Student Assessment. https://www.oecd.org/pisa/44417824.pdf

https://doi.org/10.1787/9789264077485-en

OECD (2014a). PISA in Focus 2014/4 (April). https://www.oecd.org/pisa/pisaproducts/pisainfocus/pisa-in-focus-n38-(eng)-final.pdf

OECD (2014b). PISA 2012 Results: Creative Problem Solving: Students' Skills in Tackling Real-Life Problems (Volume V). Paris: PISA, OECD Publishing.

OECD (2015). How's Life? 2015: Measuring Well-Being. Paris: OECD Publishing. https://doi.org/10.1787/how_life-2015-en

OECD (2017). PISA 2015 Results (Volume V): Collaborative Problem Solving. http://www.oecd.org/education/pisa-2015-results-volume-v-9789264285521-en.htm

Pellegrino, J. W., \& Hilton, M. L. (Eds.) (2012). Education for Life and Work: Developing Transferable Knowledge and Skills in the 21st Century. National Research Council of the National Academes. Washington DC: The National Academies Press.

PIAAC Expert Group in Problem Solving in Technology-Rich Environments (2009). PIAAC Problem Solving in Technology-Rich Environments: A Conceptual Framework. OECD Education Working Papers, No. 36, Paris: OECD Publishing.

Pienaar, K., Murphy, D., Race, K., \& Lea, T. (2018). Problematising LGBTIQ Drug Use, Governing Sexuality and Gender: A Critical Analysis of LGBTIQ Health Policy in Australia. International Journal of Drug Policy, 55, 187-194.

https://doi.org/10.1016/j.drugpo.2018.01.008

Popkewitz, T. (2004). The Alchemy of the Mathematics Curriculum: Inscriptions and the Fabrication of the Child. American Educational Research Journal, 41, 3-34.

https://doi.org/10.3102/00028312041001003

Popper, K. (2013) [1994]. All Life Is Problem Solving. New York: Routledge.

Richardson, C., Henriksen, D., Mishra, P., \& The Deep-Play Research Group (2017). The Courage to be Creative: An Interview with Dr. Yong Zhao. TechTrends, 61, 515-519. https://doi.org/10.1007/s11528-017-0221-1

Richardson, H. S. (1998). Truth and Ends in Dewey's Pragmatism, Canadian Journal of Philosophy, 28, 109-147. https://doi.org/10.1080/00455091.1998.10717497

Richardson, J. (2011). Bookforum Talks with Stanley Cavell. Bookforum. https://www.bookforum.com/interview/7169

Rorty, R. (1996). Response to Simon Critchley. In C. Mouffe (Ed.), Deconstruction and Pragmatism: Simon Critchley, Jacques Derrida, Ernesto Laclau and Richard Rorty (pp. 43-48). New York: Routledge.

Roschelle, J., \& Teasley, S. D. (1995). The Construction of Shared Knowledge in Collaborative Problem-Solving. In C. E. O’Malley (Ed.), Computer-Supported Collaborative Learning (pp. 69-97). Berlin: Springer-Verlag. https://doi.org/10.1007/978-3-642-85098-1_5

Rose, N. (2004). Becoming Neurochemical Selves. In N. Stehr (Ed.), Biotechnology, 
Commerce and Civil Society (pp. 89-128). Somerset: Transaction Publishers.

Rota, G. C. (1986). More Discrete Thoughts. In M. Kac, G.C. Rota, \& J. T. Schwartz (Eds.), Discrete Thoughts: Essays on Mathematics, Science, and Philosophy (pp. 263-264). Boston, MA: Birkhaüser-Boston. https://doi.org/10.1007/978-1-4899-6667-4_26

Saito, N., \& Standish, P. (2009). What's the Problem with Problem-Solving? Language, Skepticism, and Pragmatism. Contemporary Pragmatism, 6, 153-167. https://doi.org/10.1163/18758185-90000108

Sanderson, I. (2009). Intelligent Policy Making for a Complex World: Pragmatism, Evidence \& Learning. Political Studies, 57, 699-719. https://doi.org/10.1111/j.1467-9248.2009.00791.x

Savery, J. R., \& Duffy, T. M. (1996). Problem Based Learning: An Instructional Model and Its Constructivist Framework. In B. G. Wilson (Ed.), Constructivist Learning Environments: Case Studies in Institutional Design (pp. 135-150). Englewood Cliffs, NJ: Educational Technology Publications.

Schoenfeld, A. H. (1992). Learning to Think Mathematically: Problem Solving, Metacognition, and Sense Making in Mathematics. In D. Grouws (Ed.), Handbook for Research on Mathematics Teaching and Learning (pp. 334-370). New York: Macmillan.

Sellar, S., \& Lingard, B. (2014). The OECD and the Expansion of PISA: New Global Modes of Governance in Education. British Educational Research Journal, 40, 917-936. https://doi.org/10.1002/berj.3120

Shaw, S., \& Child, S. (2017). Utilising Technology in the Assessment of Collaboration: A Critique of PISA's Collaborative Problem-Solving Tasks. Research Matters, 24, 17-22.

Shermis, S. S., \& Barth, J. L. (1983). Problem Definition, Problem-Solving and Social Problems: Reconceptualizing the Thought Process in Education. Journal of Thought, $18,73-92$.

Simon, H. A. (1961) [1945]. Administrative Behavior: A Study of Decision-Making Processes in Administrative Organization (2nd ed.). New York: Macmillan.

Simon, H. A. (1972). Theories of Bounded Rationality. In C. B. McGuire, \& R. Radner (Eds.), Decision and Organization (pp. 161-176). Amsterdam: North-Holland Publishing Company.

Simon, H. A. (1973). The Structure of Ill Structured Problems. Artificial Intelligence, 4, 191-201. https://doi.org/10.1016/0004-3702(73)90011-8

Simon, H. A. (1978). Information-Processing Theory of Human Problem Solving. In W. K. Estes (Ed.), Handbook of Learning and Cognitive Processes (Vol. V, pp. 271-295). Hillsdale, NJ: Lawrence Erlbaum Associates.

Simon, H. S., Egidi, M., Marris, R. L., \& Viale, R. (Eds.) (1992). Economics, Bounded Rationality and the Cognitive Revolution. Cheltenham, UK: Edward Elgar.

Stahl, G. (2015). A Decade of CSCL. International Journal of Computer-Supported Collaborative Learning, 10, 337-344. https://doi.org/10.1007/s11412-015-9222-2

Sulkunen, P., \& Warsell, L. (2012). Universalism against Particularism: Kettil Bruun and the Ideological Background of the Total Consumption Model. Nordic Studies on Alcohol \& Drugs, 29, 217-232. https://doi.org/10.2478/v10199-012-0015-X

Tamboukou, M. (1999). Writing Genealogies: An Exploration of Foucault's Strategies for Doing Research. Discourse: Studies in the Cultural Politics of Education, 20, 201-217. https://doi.org/10.1080/0159630990200202

Temiz, T. (2013). Problem Solving, Creativity and Constructivist-Based Teaching Practice 
of Preservice Mathematics Teachers. Journal of Educational and Instructional Studies in the World, 3, 169-172.

Turnbull, N. (2008a). Harold Lasswell's "Problem Orientation" for the Policy Sciences. Critical Policy Analysis, 2, 72-91. https://doi.org/10.1080/19460171.2008.9518532

Turnbull, N. (2008b). Dewey's Philosophy of Questioning: Science, Practical Reason and Democracy. History of the Human Sciences, 21, 49-75. https://doi.org/10.1177/0952695107086152

Turnbull, N., \& Hoppe, R. (2018). Problematizing "Wickedness": A Critique of the Wicked Problems Concept, from Philosophy to Practice. Policy and Society, 38, 315-337. https://doi.org/10.1080/14494035.2018.1488796

Van Damme, D. (2017). Does the World Need People Who Understand Problems, or Who Can Solve Them? OECD.

https://medium.com/@OECD/does-the-world-need-people-who-understand-problems -or-who-can-solve-them-b34b7e75af76

Waldow, F. (2009). What PISA Did and Did Not Do: Germany after the "PISA-Shock". European Educational Research Journal, 8, 476-483.

https://doi.org/10.2304/eerj.2009.8.3.476

Zhao, Y. (2017). What Works May Hurt: Side Effects in Education. Journal of Educational Change, 18, 1-19. https://doi.org/10.1007/s10833-016-9294-4 